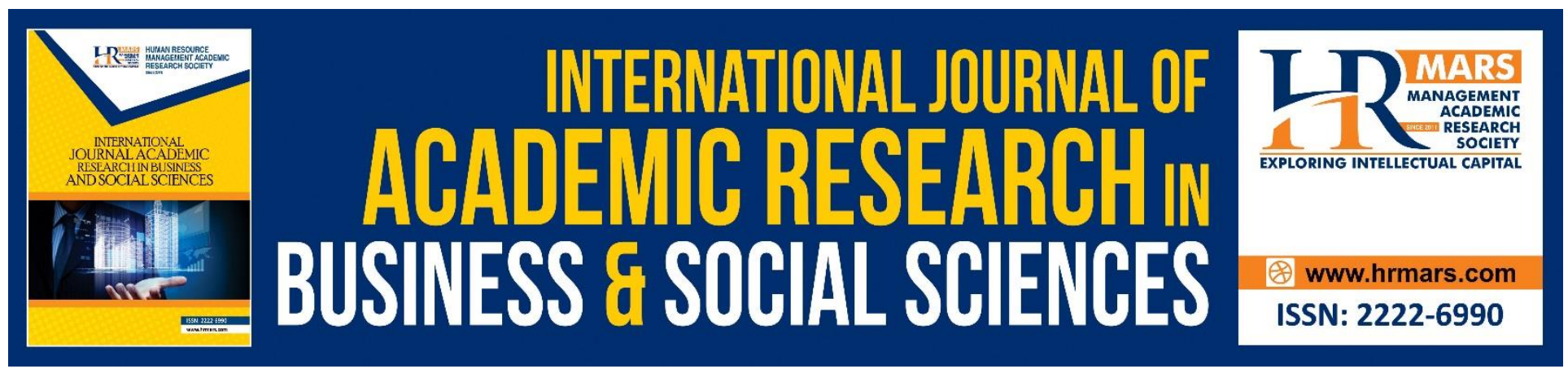

\title{
Macroeconomic Determinants and Mortgage Debt Accumulation: Evidence from Malaysia
}

Aqilah Nadiah Md Sahiq, Siti Nursyafiqah Sukardi, Noor Hasniza Haron, Shafinar Ismail, Rozana Othman

To Link this Article: http://dx.doi.org/10.6007/IJARBSS/v8-i11/4708

DOI: $10.6007 /$ IJARBSS/v8-i11/4708

Received: 21 Sept 2018, Revised: 13 Oct 2018, Accepted: 16 Oct 2018

Published Online: 23 Nov 2018

In-Text Citation: (Sahiq, Sukardi, Haron, Ismail, \& Othman, 2018)

To Cite this Article: Sahiq, A. N. M., Sukardi, S. N., Haron, N. H., Ismail, S., \& Othman, R. (2018). Macroeconomic Determinants and Mortgage Debt Accumulation: Evidence from Malaysia. International Journal of Academic Research in Business and Social Sciences, 8(11), 97-113.

Copyright: (c) 2018 The Author(s)

Published by Human Resource Management Academic Research Society (www.hrmars.com)

This article is published under the Creative Commons Attribution (CC BY 4.0) license. Anyone may reproduce, distribute, translate and create derivative works of this article (for both commercial and non-commercial purposes), subject to full attribution to the original publication and authors. The full terms of this license may be seen

at: http://creativecommons.org/licences/by/4.0/legalcode

Vol. 8, No. 11, 2018, Pg. 97 - 113

http://hrmars.com/index.php/pages/detail/IJARBSS

JOURNAL HOMEPAGE

Full Terms \& Conditions of access and use can be found at http://hrmars.com/index.php/pages/detail/publication-ethics 


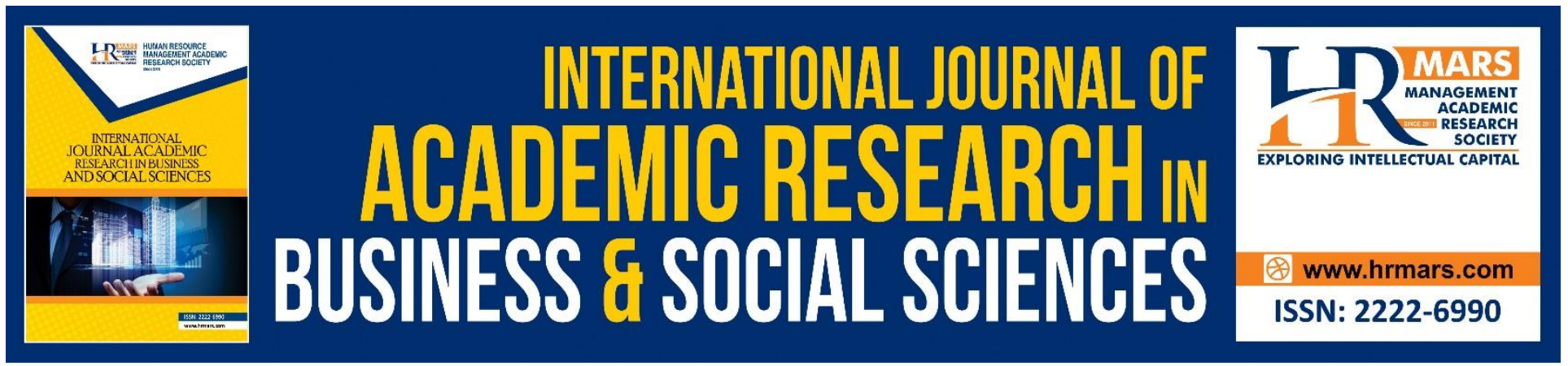

\title{
Macroeconomic Determinants and Mortgage Debt Accumulation: Evidence from Malaysia
}

\author{
Aqilah Nadiah Md Sahiq \\ Faculty of Business and Management, Universiti Teknologi MARA Cawangan Melaka, \\ Kampus Bandaraya Melaka, Malaysia \\ Siti Nursyafiqah Sukardi \\ Faculty of Business and Management, Universiti Teknologi MARA Cawangan Melaka, \\ Kampus Bandaraya Melaka, Malaysia \\ Noor Hasniza Haron \\ Faculty of Accountancy, Universiti Teknologi MARA Cawangan Selangor, \\ Kampus Puncak Alam, Malaysia

\section{Shafinar Ismail} \\ Faculty of Business and Management, Universiti Teknologi MARA Cawangan Melaka, \\ Kampus Bandaraya Melaka, Malaysia

\section{Rozana Othman} \\ Faculty of Business and Management, Universiti Teknologi MARA Cawangan Melaka, \\ Kampus Bandaraya Melaka, Malaysia
}

\section{Abstract}

The statistics of the household debt in Malaysia is among the highest in the ASEAN region with the biggest portion of the household debt goes to pay off the mortgage debt. As accommodation is one of the basic needs required by all households regardless of the price offered, concerns are given to the household affordability to live in a decent economy. The escalating trend of household debts related to mortgage is due to the increase in house prices, fluctuation in interest rates and speculative activities taken by investors. Thus, the aim of the study is to examine the relationship of principal drivers on mortgage debt accumulation using macroeconomic determinants.

The macroeconomic determinants were represented by house price index (HPI), interest rate $(\mathrm{IR})$, gross domestic product (GDP) and living cost (LC). The data set was analyzed between the period 
of 2006 till 2016 on a quarterly basis. Multiple regression analysis was applied to test the statistical relationship between the macroeconomic determinants and the mortgage debt. Several diagnostic tests also being conducted to ensure that the proposed model in this study adequately describes the time series under consideration.

The empirical findings revealed that the accumulation of mortgage debt in Malaysia is driven primarily by three key factors: house price index, interest rate, and living cost. The living cost has been identified as the most significant factor that leads to high accumulation of mortgage debt in Malaysia. However, income (which is represented by GDP) does not give any significant impact towards the accumulation of mortgage debt. This implies that capital appreciation in the property market has made households stretch out their mortgage financing to own a house to fulfill their basic needs; without considering their level of income.

The implication of this study is critical to deliberate for further analysis as easy access to mortgage debt may lead to default or sub-prime crisis. By understanding the principal macroeconomic drivers that influence the accumulation of mortgage debt, this would contribute to the body of knowledge, and subsequently the legislator who can take the necessary actions to mitigate the issues of escalating prices in the property market, and how best to balance between the macroeconomic policy and the related policies designed to stabilize the housing market, and to contain the mortgage debt from upward bubbling.

Keywords: Mortgage Debt, House Price Index, Interest Rate, Gross Domestic Product, Living Cost

\section{Introduction}

The residential property serves as a basic human need and plays a significant part in the economic development since the debate began in the early 1950s (Arku, 2006). The real estate demand and quality expectation have increased in tandem with the living standards of individuals and households. The urbanization and housing issues have also contributed to the growing demand for mortgage debt in Malaysia. Malaysia is a developing country with the highest record of household debt in the ASEAN region (Tong, 2018). The biggest portion of the Malaysian household debt goes to paying off the housing loans (52\%), followed by personal financing (14.6\%), motor vehicles (14.1\%), non-residential loan (7\%), securities purchase (5.5\%), credit card (3.4\%), and other items (3.3\%)(Bank Negara Malaysia, 2017). Commitments for higher mortgage debt may put the borrower in the brink of insolvency or bankruptcy. Concerns arise when households are unable to make timely payment on their financial obligations. Late payment and high interest rate attached to the loan may increase the outstanding amount to be paid. Default loan payment might damage household credit rating or worst, the household savings or current account might be seized to pay off the outstanding amount. The main reason why Malaysian households take up a huge amount of housing loans is due to the necessity of owning a home, despite the escalating house prices which gives rise to the housing affordability issue. Besides that, the low or negative interest rates and speculative activities also contribute significantly to the growing number of housing loans (Bank Negara Malaysia, 2017).

Given these arguments, the motivation of this study is to examine the relationship of principal drivers on mortgage debt accumulation using macroeconomic determinants. The macroeconomic determinants are represented by house price index (HPI), interest rate (IR), gross domestic product (GDP) and living cost (LC). Considering that the mass of household sector lending is actually for 
mortgage loans along with automobile lending, the distribution of household sector debt is very likely to be vulnerable.

The contribution of the study provides two key insights. First, it highlights the importance of understanding the economic mechanisms that trigger mortgage debt accumulation and the rise in default rates. Insights into these issues may serve to improve the policy on how to prevent future mortgage crises or mitigate those that have already started as mortgages may not always be a productive debt. Second, the contribution of this paper is to assess the hypotheses empirically; and thus, expands the framework of analysis of emerging literature on household debt accumulation. While credit may help consumers to alleviate the impact of negative income shocks, the accumulation of household debt can make households vulnerable to such shocks. Indeed, a large number of empirical contributions indicate that household debt has a positive direct impact on long-run economic growth; but it may also have indirect negative effects in the shorter term (Brown, Haas, and Grosjean, 2012; Ehrmann and Ziegelmeyer, 2017; Zabai, 2017). However, existing literature on the determinants of mortgage debt accumulation is rather thin; where most studies focused on advanced economic countries such as the United States (Foote, Loewenstein, and Willen, 2016; Schelkle, 2018), the OECD countries (Stockhammer \& Wildauer, 2017) and the European regions (Brown et al., 2012). Thus, the existing literature lacks a comprehensive empirical study, especially in the Malaysian setting (Ma'in, Ismarau Tajuddin, and Saiful Nathan, 2016; Nizar, 2016). Assessing the explanatory power of these hypotheses is not only interesting from a theoretical perspective, but also for the economic policy because they give different policy implications.

The rest of the paper is organized as follows. In the next section, the literature reviews and hypothesis development will be presented. Then, the methodology of the study is explained; followed by critical analysis of the empirical findings. Finally, the conclusion, suggestions, and limitations of future research are reported in the last section.

\section{Literature Review and Hypotheses Development Concept of Mortgage Debt}

Mortgage financing is a loan in which a property is obtained under a lawful contract. Mortgage debt is repaid on legally agreed upon terms including its amortization period, varying or fixed-term interest rates, recurrence of payments, and any additional payments to pay off the principal or penalties for missed payments and other foreclosures (Chawla, 2011). In advanced economies, mortgage debt makes up the bulk of household debt, but less so in emerging market economies. It accounts for more than 50 percent of total household debt in most advanced economies, whereas among the emerging market economies it captures only one-third or less of total household debt (International Monetary Fund, 2017).

In Malaysia, mortgage applications have been rising every month since the start of the year 2017. The approval rate for housing loans is also rising. According to the latest Bank Negara Malaysia statistics, May 2017 saw a 42.13\% approval rate after it was down at 39.83\% in March 2017 (Goh, 2017). The uptick in loan applications and approvals can be attributed to several factors such as developers launching more mid-range and affordable properties, and in the secondary market, sellers becoming more realistic in their asking prices. More importantly, there is now a constant flow of buyers who are purchasing properties to stay, rather than as an investment. Hence, the demand for 
INTERNATIONAL JOURNAL OF ACADEMIC RESEARCH IN BUSINESS AND SOCIAL SCIENCES Vol. 8, No. 11, Nov, 2018, E-ISSN: 2222-6990 @ 2018 HRMARS

mortgage debt in Malaysia continues to rise, as housing is an important source of collateral for household loans and can also being viewed as a commodity that is subjected to large fluctuations. In addition, the mortgage market is important for macroeconomic development because it is an indication that the economic situation is improving.

\section{Concept of House Price Index (HPI) with Mortgage Debt}

The house Price Index (HPI) is considered as an important indicator to a few groups of stakeholders (such as speculators, house buyers, lenders and property developers). This makes it a source of perspective that demonstrates the current state of real property market in Malaysia. The Malaysian House Price Index (MHPI) is recorded by the National Property Information Centre (NAPIC). Hoang and Meng (2015) expressed in their study that the expansion in housing price will discourage households to purchase properties in Australia. Similarly, Geiger, Muellbauer, and Rupprecht (2016) found negative relationship for HPI and mortgage debt as household members may purchase the house when the market is stable and make credit consumption during a stable period.

However, most of the previous studies reported that mortgage debt has a positive relationship with the house price index (Ma'in, et al., 2016; Atalay, Barrett, and Edwards, 2015; Valverde and Fernández, 2010; Fortin, 2014; Panagiotidis and Printzis, 2015; Bollano and Ziu, 2009; Gerlach and Peng, 2005). For instance, Ma'in et al. (2016) found that there is a positive relationship between the house price and mortgage debt in Malaysia; where an increase of $10 \%$ of the house price in Malaysia, will increase the mortgage debt by $4.99 \%$. The demand for housing stays solid despite the rise in the housing cost. This outcome has led to a fast increment in the benefits of housing loans. Jacobsen and Naug (2004) highlighted that household debt in Norway may increase further because a higher house price may result in higher financial wealth (inheritance) and better borrowing conditions. These households will then have a greater incentive to raise loans secured by the collateral in their dwelling to finance their consumption and investment. Hence, based on the extensive literature that has been conducted, the first hypothesis is developed as follows:

$\mathrm{H}_{1}$ : There is a significant relationship between the house price index and mortgage debt accumulation in Malaysia.

\section{Concept of Interest Rate (IR) with Mortgage Debt}

Interest Rate (IR) is the borrowing costs of the assets that are granted to the borrower by a lender. Martins and Villanueva (2004) discovered that an expansion in interest rates by $1 \%$ reduces the probability of a loan by $2.9 \%$. Similarly, Crawford and Faruqui (2012) found that when the interest rates fall, the demand for mortgage credit grows and thus, stimulating both prices and household debt. This finding is similar to the work of Fortin (2014); Eccleston, Churchill, and Smith, (2014); and Leece (2006) which state that low interest rates have also contributed to the increased volumes of home ownership and mortgage debt. Meanwhile, higher interest rates will contribute to lesser demand on the mortgages secured by real property (Consumer Financial Protection Bureau (CFPB), 2014). When the interest rate increase, but the money supply declines, then the credit consumption will weaken, hence the demand for housing will declining (Igan, Kabundi, Nadal De Simone, Pinheiro, 
INTERNATIONAL JOURNAL OF ACADEMIC RESEARCH IN BUSINESS AND SOCIAL SCIENCES

Vol. 8, No. 11, Nov, 2018, E-ISSN: 2222-6990 @ 2018 HRMARS

and Tamirisa, 2011; Apergis and Rezitis, 2003). Therefore, this literature leads to the second hypothesis development as follows:

$\mathrm{H}_{2}$ : There is a significant relationship between the interest rate and mortgage debt accumulation in Malaysia.

\section{Concept of Income (INC) with Mortgage Debt}

Studies done by Jacobsen and Naug (2004), Kok (2016), Mian and Sufi (2009), and Pettinger (2017) revealed that there is a positive relationship between gross domestic product and mortgage debt. High gross domestic products will encourage businesses to open their doors for semi-talented specialists and enterprises related to housing divisions like steels, wood, paintings and construction materials, hence encouraging genuine financial development and asset creation (Saeed, 2011). The increase in the mortgage debt in Malaysia will boost the economy growth as more money is being spent. However, the decrease in income will leave the people with less money to spend, which may cause them to fall behind in their mortgage payments and end up with their home being repossessed (Pettinger, 2017). Using gross domestic product as a proxy to income, this research has developed the third hypothesis as follows:

$\mathrm{H}_{3}$ : There is a significant relationship between the income and mortgage debt accumulation in Malaysia.

\section{Concept of Living Cost (LC) with Mortgage Debt}

The Consumer Price Index (CPI) is the current social and economic indicator constructed to calculate changes over time in the general level of prices of consumer goods and services that representing the average pattern of purchases made by a particular population in a specified time period (Department of Statistics Malaysia Official Portal, 2015). As the CPI reflects average prices in the economy, it provides a good measure of the changes in the overall price level of goods and services in the economy. The cost of living, on the other hand, refers to the amount of expenditure on goods and services incurred by households, including their financial obligations to maintain a certain standard of living (Bank Negara Malaysia, 2015). This spending or cost of living is determined by both household spending patterns and the prices faced by households. Spending patterns differ across households as the patterns are primarily influenced by household income, demography, family structure and the area of residence. Price changes faced by households, in turn, vary by geographical factors. The CPI masks the heterogeneity in household spending patterns and the variations in price changes of goods and services faced by households. The main weightage in the Consumer Price Index (CPI) is food price which reflects the living cost, and hence the food price index is used as a proxy in this study.

The current residential market in Malaysia (for the year 2018) is expected to remain weak due to the growing uncertainties in the environment and the rising cost of living. This has led to a mismatch between the asking prices of a property and the income of prospective buyers (Citibank, 2018). A similar situation happens in Northern Europe where young adults delay in purchasing a house due to the high borrowing costs (Martins and Villanueva, 2009). In addition, Eccleston et al. 
(2014) and Marsden (2015) discovered that there is a positive relationship between the cost of living and mortgage debt. The results revealed that the increase in the cost of living will affect the wellbeing and the prosperity of a household due to the sub-standard living conditions, with the view of the family do not have strong commitments to pay their financial obligations. However, Ahmad Khan, Abdullah, and Samsudin (2016) conducted research on household debt in Malaysia from 1999 until 2014 using autoregressive distributed lag modelling approach (ARDL), found that there is a negative relationship between the food price index and mortgage debt. Households will reduce their spending on assets such as properties by $2.77 \%$ when the cost of living increases by $1 \%$. Hence, the above literature forms the basis of the fourth hypothesis as follows:

$\mathrm{H}_{4}$ : There is a significant relationship between the living cost and mortgage debt accumulation in Malaysia.

\section{Research Methodology Data Collection}

The study used quarterly data collected from various sources such as the Department of Statistics Malaysia (DoSM), Bank Negara Malaysia (BNM) and the International Monetary Fund (IMF) for ten (10) years, from the period of 2006 to 2016. The time series data was analyzed using E-Views. The data was converted into logarithm to standardize the entire figures. The list of variables is presented in Table 1.

Table 1: Summary of Variables

\begin{tabular}{|c|c|c|c|c|}
\hline \multirow{2}{*}{$\frac{\text { VARIABLES }}{\text { Mortgage Debt }}$} & \multirow{2}{*}{$\frac{\text { ACRONYM }}{\text { MD }}$} & MEASUREMENT & \multicolumn{2}{|c|}{ SOURCE } \\
\hline & & $\begin{array}{l}\text { Loan disbursed by purpose: } \\
\text { Purchase of Residential Property }\end{array}$ & $\begin{array}{l}\text { Bank Negara } \\
\text { (BNM) }\end{array}$ & Malaysia \\
\hline $\begin{array}{l}\text { House } \quad \text { Price } \\
\text { Index }\end{array}$ & $\mathrm{HPI}$ & $\begin{array}{l}\text { Annual percentage change based } \\
\text { on house type }\end{array}$ & $\begin{array}{l}\text { National } \\
\text { Information } \\
\text { (NAPIC) }\end{array}$ & $\begin{array}{r}\text { Property } \\
\text { Centre }\end{array}$ \\
\hline Interest Rate & IR & Base Lending Rate & $\begin{array}{l}\text { Bank Negara } \\
\text { (BNM) }\end{array}$ & Malaysia \\
\hline Income & INC & Gross Domestic Product (\%) & $\begin{array}{l}\text { International } \\
\text { Fund (IMF) }\end{array}$ & Monetary \\
\hline Living Cost & LC & Food Price Index (FPI) & $\begin{array}{l}\text { Department of } \\
\text { Malaysia (DoSM }\end{array}$ & Statistics \\
\hline
\end{tabular}

The Unit Root Test was conducted using the Augmented Dickey-Fuller (ADF) statistics to test the stationarity of the data. This was then followed by the regression analysis. Many economic and financial time series data exhibit trending behavior or non-stationarity in the mean and have an 
infinite variance (Zivot and Wang, 2006). Thus, unit roots can cause unpredictable and bias results in time series analysis; and spurious correlations are very likely to emerge in non-stationary data. The smaller the value (negative value), the stronger the evidence for the data to be stationary (Dickey and Fuller, 1981; Zivot and Wang, 2006).

\section{Model Estimation}

A multiple regression model was used to test the hypothesis of the study. The empirical model that was used for the analysis was developed as follows:

$$
M D_{Y}=\beta_{0}+\beta_{1} H P I+\beta_{2} I R+\beta_{3} I N C+\beta_{4} L C+\varepsilon
$$

where,

MD : Mortgage Debt

ßo : Constant variable

HPI : House Price Index

IR : Interest Rate

INC : Income

LC : Living Cost

$\varepsilon \quad:$ Normally distributed error term

The observation of the dependent variable $(Y)$ was represented by mortgage debt. Meanwhile, the independent variables were represented by the selected macroeconomic determinants (HPI, IR, INC and LC) based on previous literature. The associated regression coefficients were represented by beta ( $($ ). Several diagnostic tests were conducted to ensure that the proposed model in this study adequately describes the time series under consideration by subjecting the calibrated model to a range of statistical tests such as the Jarque-Bera Normality Test, the BreuschGodfrey LM Test, the White Test, the Ramsey's Reset Test, and the Multicollinearity Test.

\section{Findings and Discussions}

\section{Unit Root Test}

Firstly, the Unit Root Test was conducted using the Augmented Dickey-Fuller (ADF) statistics to test the stationarity of the data. The outcomes obtained from the Augmented-Dickey Fuller Test, as presented in Table 2, indicates that the data regarding Mortgage Debt (MD), House Price Index (HPI), Interest Rate (IR), Income (INC) and Living Cost (LC), are all stationary at level of significance at first difference whereby all the $p$-values are less than 0.10 of critical values. 
INTERNATIONAL JOURNAL OF ACADEMIC RESEARCH IN BUSINESS AND SOCIAL SCIENCES Vol. 8, No. 11, Nov, 2018, E-ISSN: 2222-6990 @ 2018 HRMARS

Table 2: Augmented Dickey Fuller (ADF) Test

\begin{tabular}{|c|l|l|l|l|}
\hline \multirow{2}{*}{ VARIABLES } & \multicolumn{2}{|c|}{ LEVEL } & \multicolumn{2}{c|}{ FIRST DIFFERENCE } \\
\cline { 2 - 5 } & \multicolumn{1}{|c|}{ NO TREND } & \multicolumn{1}{c|}{ WITH TREND } & \multicolumn{1}{c|}{ NO TREND } & \multicolumn{1}{c|}{ WITH TREND } \\
\hline \multirow{2}{*}{ MD } & -1.4519 & -2.3758 & -5.9193 & -6.8514 \\
& 0.5480 & 0.3864 & $0.0000^{* * *}$ & $0.0000^{* * *}$ \\
\hline \multirow{2}{*}{ HPI } & -1.7110 & -1.2422 & -9.1654 & -9.2741 \\
& 0.4187 & 0.8886 & $0.0000^{* * *}$ & $0.0000^{* * *}$ \\
\hline \multirow{2}{*}{ IR } & -2.5832 & -2.8609 & -3.9268 & -3.9053 \\
& 0.1044 & 0.1851 & $0.0041^{* * *}$ & $0.0205^{* *}$ \\
\hline \multirow{2}{*}{ INC } & -4.8025 & -4.7515 & -7.4245 & -7.3333 \\
& $0.0003 * * *$ & $0.0022^{* * *}$ & $0.0000^{* * *}$ & $0.0000^{* * *}$ \\
\hline \multirow{2}{*}{ LC } & -1.3403 & -1.7492 & -6.1306 & -6.0625 \\
& 0.6022 & 0.7116 & $0.0000^{* * *}$ & $0.0000^{* * *}$ \\
\hline
\end{tabular}

Note: ***Significant at the $1 \%$ level, ** Significant at the $5 \%$ level, * Significant at the $10 \%$ level

\section{Descriptive Statistics}

Table 3 shows the summary of descriptive statistics of quarterly data on macroeconomic variables from the year 2006 till 2016 with a total number of 44 observations.

Table 3: Descriptive Statistics

\begin{tabular}{|c|c|c|c|c|c|}
\hline & $\mathrm{LOG}_{\mathrm{INC}}$ & $\mathrm{LOG}_{\mathrm{HPI}}$ & $\mathrm{LOG}_{\mathbb{R}}$ & $\mathrm{LOG}_{\mathrm{LC}}$ & $\mathrm{LOG}_{\mathrm{MD}}$ \\
\hline Mean & 2.287529 & 1.765339 & 1.868054 & 4.713619 & 1.677438 \\
\hline Median & 2.416352 & 1.938716 & 1.877682 & 4.706220 & 1.742079 \\
\hline Maximum & 2.783776 & 2.501436 & 1.917413 & 4.829380 & 2.062579 \\
\hline Minimum & -1.427116 & -0.356675 & 1.706565 & 4.595120 & 1.127329 \\
\hline Std. Dev. & 0.648037 & 0.651476 & 0.059284 & 0.069181 & 0.284656 \\
\hline Skewness & -4.709487 & -1.273349 & -1.745607 & 0.047194 & -0.510584 \\
\hline Kurtosis & 26.38230 & 4.351503 & 5.011938 & 1.730316 & 2.074183 \\
\hline Jarque-Bera & 1164.990 & 15.23910 & 29.76687 & 2.971847 & 3.483187 \\
\hline Probability & $0.000000 * * *$ & $0.000491 * * *$ & $0.000000 * * *$ & 0.226293 & 0.175241 \\
\hline Sum & 100.6513 & 77.67494 & 82.19437 & 207.3992 & 73.80728 \\
\hline Sum Sq. Dev. & 18.05796 & 18.25008 & 0.151125 & 0.205801 & 3.484257 \\
\hline Observations & 44 & 44 & 44 & 44 & 44 \\
\hline
\end{tabular}

The mean for all variables is positive ranging from 1.677438 to 4.713619 . The mean for all the variables, except for the living cost, is greater than the median value. This indicates that, the distribution of data for all the variables, except for the living cost, appear to be skewed to the right. 
The dispersion of the data is reflected by the measure of standard deviation. All the variables are spread within the range of 0.059284 to 0.651476 . The housing price index recorded the highest volatility at 0.651476 while the Interest Rate has the lowest volatility at 0.059284 . In terms of skewness, the living cost is positively skewed at 0.047194 while for the other variables they are negatively skewed.

The Kurtosis result for the mortgage debt and living cost shows that the variables are measured as a platykurtic distribution with a value of less than 3, at kurtosis values of 2.074183 and 1.730316 respectively. The platykurtic distribution is represented with less peaked in the mean and thinner tails compared to the normal distribution (i.e. flatter distribution). Meanwhile, the leptokurtic distribution was reflected for the house price index, the interest rate and income with the values of $4.351503,5.011938$ and 26.38230 respectively; which are more than 3 . This indicates that the distribution of the data has fatter tails and sharper peak compared to the normal distribution (i.e. peaked distribution).

Finally, based on the Jarque-Bera test, the data for the mortgage debt and living cost are normally distributed since the $p$-value is more than 0.1 . However, the data distribution of the house price index, the interest rate and income are not normally distributed since the $p$-value is less than 0.1. This reflects that the data for HPI, IR and INC might have outliers and therefore should be cautiously interpreted.

\section{Regression Analysis}

Based on the regression analysis result showned in Table 4, the housing price index and the living cost have positive and significant relationship with mortgage debt accumulation with less than 0.01 critical values whilst the interest rate has a significant negative p-value of less than 0.10 of the critical value. However, income is found to be an insignificant determinant in influencing the mortgage debt accumulation. The living cost has the highest coefficient beta value at 2.315456, indicating that the living cost is the most significant macroeconomic determinant of mortgage debt accumulation. Precisely, $73.88 \%$ of the variation in the mortgage debt accumulation can be explained by the housing price index, the interest rate, the income and the living cost. Overall, the proposed model of this study is fit and acceptable since the $p$-value of the F-test is 0.00000 in which the value is lower than 0.01. The output of the regression analysis is presented as per below equation:

$$
M D t=-8.322988+0.345517_{H P I}-0.772149_{I R}-0.035536_{I N C}+2.315456_{L C}
$$

Table 4: Multiple Linear Regressions Model Empirical Result

\begin{tabular}{lcl}
\hline \multicolumn{1}{c}{ Item } & \multicolumn{1}{c}{ Coefficient Value } & p-value \\
\hline Bo & -8.322988 & 0.0000 \\
House Price Index (HPI) & 0.345517 & $0.0000^{* * *}$ \\
Interest Rate (IR) & -0.772149 & $0.0895^{*}$ \\
Income (INC) & -0.035536 & 0.4892 \\
Living Cost (LC) & 2.315456 & $0.0000^{* * *}$ \\
\hline R-Squared & 0.738834 & \\
Adjusted R-Squared & 0.712047 & \\
Number Observation & 44 & 0.00000 \\
F-statistics & 27.58251 & \\
\hline \multicolumn{2}{c}{ Notes: Significant at } & \\
\end{tabular}


INTERNATIONAL JOURNAL OF ACADEMIC RESEARCH IN BUSINESS AND SOCIAL SCIENCES

Vol. 8, No. 11, Nov, 2018, E-ISSN: 2222-6990 (C) 2018 HRMARS

To answer the research objectives, Table 5 below shows the list of hypotheses and the verdicts of the hypotheses testing.

Table 5: Summary of Hypothesis Testing

Diagnostic Tests

\begin{tabular}{|c|c|}
\hline Hypothesis & Findings \\
\hline $\begin{array}{l}\mathrm{H}_{1} \text { : There is a significant relationship } \\
\text { between the house price index (HPI) and } \\
\text { the mortgage debt accumulation in } \\
\text { Malaysia. }\end{array}$ & $\begin{array}{l}\text { The first hypothesis for this study is accepted. The } \\
\text { result for the house price index is significant and has } \\
\text { a positive relationship with the mortgage debt. This is } \\
\text { due to the escalating trend of housing price in } \\
\text { Malaysia. Many households would grab the } \\
\text { opportunity to purchase a house for residential rather } \\
\text { than investment purposes before the price gets more } \\
\text { expensive. The result of this study is similar to } \\
\text { previous studies done by Ma'in, et al., (2016), Kok } \\
\text { (2016), Atalay et al., (2015), and Nizar (2016). }\end{array}$ \\
\hline $\begin{array}{l}\mathrm{H}_{2} \text { : There is a significant relationship } \\
\text { between the interest rate and the } \\
\text { mortgage debt accumulation in Malaysia. }\end{array}$ & $\begin{array}{l}\text { The second hypothesis is accepted for the study and } \\
\text { aligned with some previous studies done by Eccleston } \\
\text { et al. (2014), Fortin (2014), and Crawford and Faruqui } \\
\text { (2012). The higher interest rate would create lesser } \\
\text { demand for mortgage debt. There is a possibility that } \\
\text { households in Malaysia could not afford to pay higher } \\
\text { interest rate as this means higher monthly payments, } \\
\text { which crimps out the household affordability. }\end{array}$ \\
\hline $\begin{array}{l}\mathrm{H}_{3} \text { : There is a significant relationship } \\
\text { between the income and the mortgage } \\
\text { debt accumulation in Malaysia. }\end{array}$ & $\begin{array}{l}\text { The third hypothesis is rejected. The income does not } \\
\text { appear to be materially significant towards the } \\
\text { mortgage debt accumulation in Malaysia. The result is } \\
\text { similar to a study done by Dynan and Kohn (2007). }\end{array}$ \\
\hline $\begin{array}{l}\mathrm{H}_{4} \text { : There is a significant relationship } \\
\text { between the living cost and the mortgage } \\
\text { debt accumulation in Malaysia. }\end{array}$ & $\begin{array}{l}\text { The fourth hypothesis is accepted. The higher cost of } \\
\text { living will encourage households to engage in } \\
\text { mortgage debt to enhance their quality of life, besides } \\
\text { fulfilling their basic needs. The result is supported by } \\
\text { previous studies by Eccleston et al., (2014), Jasthi } \\
\text { (2015), and Marsden (2015). }\end{array}$ \\
\hline
\end{tabular}

Several diagnostic tests were conducted to ensure that the proposed model in this study adequately describes the time series under consideration by subjecting the calibrated model to a range of statistical tests as summarized in Table 6. 
INTERNATIONAL JOURNAL OF ACADEMIC RESEARCH IN BUSINESS AND SOCIAL SCIENCES

Vol. 8, No. 11, Nov, 2018, E-ISSN: 2222-6990 @ 2018 HRMARS

Table 6: Results for the Diagnostic Tests on Multiple Linear Regression Model

\begin{tabular}{llc}
\hline & \multicolumn{1}{c}{ Diagnostic Tests } & p-value \\
\hline (i) & Jarque-Bera Normality Test & 0.5041 \\
(ii) & Breusch-Godfrey LM Test & 0.0112 \\
(iii) & White Test & 0.0801 \\
(iv) & Ramsey's Reset Test & 0.0606 \\
(v) & Multicollinearity Test & \\
& Independent Variable & Variance Inflation Factors (VIF) \\
& a. HPI & 1.120586 \\
& b. IR & 1.109018 \\
c. LC & 1.032357 \\
d. INC & 1.071775 \\
\hline
\end{tabular}

The data was subjected to a normality test because the regression analysis was based on the assumption that the data was normally distributed. If the data is not normal, then the results will be misleading. Hence, the first diagnostic checking that was conducted was the Jarque-Bera test to determine whether the model error terms were normally distributed (Brooks, 2008). It can be concluded that the multiple linear regression model error terms were normally distributed with a $p$ value of 0.5041 , which was higher than the significant level $\alpha, 0.10$.

After conducting the Jarque-Bera test, the Breusch-Godfrey LM Test was conducted to find out the existence of any autocorrelation problem between variables. Autocorrelation refers to the time series correlation and are sometimes called the lagged correlation or serial correlation (Brooks, 2008). The result in Table 6 shows a p-value of 0.0112 , which was more than the significant level of 0.01 . The result indicates that no autocorrelation problem existed. Therefore, the data used were serially independent from the error term.

Next, the White Test was performed to discover heteroscedasticity problems. When the error term differ across the observations, heteroscedasticity is present (Brooks, 2008). The standard errors of the estimates are distorted if heteroscedasticity exists. Based on Table 6 , the p-value for this test was 0.0801 , which was greater than the significant value of 0.01 and 0.05 . This demonstrates that the sample error term was homoscedasticity, which means the errors have constant variance. The value also indicates that heteroscedasticity issues did not exist.

Next, the Ramsey's Reset Test was carried out to determine whether the model was correctly specified. Based on the result in Table 6, the p-value for t-statistic was greater than the significance level of 0.05 and 0.01 , which was 0.0606 . This indicates that the multiple linear regression model was not mis-specified, or that the multiple linear regression model was linear.

Finally, the Multicollinearity Test was conducted using the variance inflation factors (VIF) to determine the correlation between independent variables. The result of VIF for all variables was less than 10, indicating a high-quality result where there was no serious multicollinearity problem (Brooks, 2008). Otherwise, the regression coefficients were weakly estimated due to 
multicollinearity. In addition, the errors of the constant variance did not show any heteroscedasticity problem for the variance inflation factor.

In summary, the results show that the multiple linear regression model was normally distributed, not mis-specified, and that the independent variables did not have serious multicollinearity problems. Therefore, it can be concluded that the model is free from heteroscedasticity problem and that no autocorrelation problems exist.

\section{Conclusion}

This study highlights the importance of understanding the economic mechanisms that trigger mortgage debt accumulation in Malaysia, spanning from the period of 2006 to 2016. The empirical findings revealed that the accumulation of mortgage debt in Malaysia is driven primarily by three key factors: the house price index, the interest rate, and the living cost. The living cost has been identified as the most significant factor that leads to the high accumulation of mortgage debt in Malaysia. However, income (which is represented by GDP) does not give any significant impact towards the accumulation of mortgage debt.

Based on the empirical results, this implies that capital appreciation in the property market has made households stretch out their mortgage financing to own a house in order to fulfill their basic needs without considering their level of income. The credit market competition and greater credit availability may have made households become less sensitive to changes in income, despite the runup in accumulating mortgage debt. However, this result should not be taken as a generalization of the Malaysian households as excessive accumulation of mortgage debt could lead to financial distress.

Due to the increase in housing price, many households in Malaysia have grabbed the opportunity of acquiring properties for their own use, rather than as an investment. Hence, the demand for mortgage debt in Malaysia continues to increase. This will remain sustainable as Malaysia progresses to become a developed nation with an increased rate of migration to urban centres such as the Klang Valley, Penang and Johor Baru. Therefore, applications for mortgage are increasing.

Higher interest rates also have several effects on mortgage debt accumulation. First, higher rates are generally associated with a stronger economy. That means wages are generally rising, making that home more affordable; and borrowers are more confident about their job status, making them more willing to borrow to buy a home. In addition, higher interest rates are often associated with inflationary periods, during which real assets, such as homes, rise in value. Offsetting this, higher interest rates mean higher monthly payments, which may crimp out purchasing affordability. And with lower affordability, an increase in the interest rate may become a hurdle for the households to purchase any property as they may not afford to pay high financing charges.

Nevertheless, the higher cost of living may induce households to find alternatives to purchase a residential property such as seeking for a property in the secondary market as some speculators are willing to dispose of their properties for lower gains or even sold them off at their purchase price due to the lackluster property market and the low rental yield in Malaysia. 


\section{Recommendations for Future Research}

In summary, mortgages constitute the largest part of household debt, and a large literature has highlighted on modelling the determinants of household debt; but limited research has focused on the extent to which macroeconomic conditions come into play towards mortgage debt accumulation. It is critical to understand the economic mechanisms that trigger mortgage debt accumulation due to the rise in default rates. Insights into these issues may serve to improve the policy on how to prevent future mortgage crises or mitigate those that have already started. When a borrower purchases a home and then makes a series of on-time payments, the individual's credit score typically rises. However, a great deal of new debt is taken out by individuals with relatively low scores. People typically borrow to buy homes early in their adult lives. However, on average, young people have low credit scores because they have yet to build up substantial savings, and they have relatively short histories of paying bills on time.

Therefore, it is imperative for regulators and the financial sectors to have effective collaboration, to educate potential consumers to possess credit rating scores prior to acquiring housing loans. The fact is, the household sector is the solitary contributor for Malaysian financial institutions, accounting for about $55 \%$ of banking sector loans; yet mortgages may not always be a productive debt.

This study has certainly raised several issues for further investigation. However, caution in interpreting the results is nevertheless needed, especially in view of limited data availability, quality and comparability. It would be good if the data is made available to the public so that it can be used to get better results. In this study, the data was limited to ten (10) years only and observed on a quarterly basis. It is also highly recommended to expand the observation period and include more variables which are relevant for future research such as the loan to value ratio, population and inflation rate to help identify other determinants of mortgage debt accumulation.

\section{Acknowledgement}

Special thanks to the Department of Research, Industrial \& Alumni Network (PJIA) of Universiti Teknologi MARA (UiTM) Cawangan Melaka for subsidizing the publication fee of this article.

\section{Corresponding Author}

Aqilah Nadiah Md Sahiq

Faculty of Business and Management

Universiti Teknologi MARA Cawangan Melaka

Kampus Bandaraya Melaka

Malaysia

Email: aqilah_nms@yahoo.co.uk

\section{References}

Ahmad Khan, H. H., Abdullah, H., and Samsudin, S. (2016). Modelling the determinants of Malaysian household debt. International Journal of Economics and Financial Issues, 6(4), 1468-1473.

Apergis, N., and Rezitis, A. (2003). Housing prices and macroeconomic factors in Greece: prospects 
INTERNATIONAL JOURNAL OF ACADEMIC RESEARCH IN BUSINESS AND SOCIAL SCIENCES

Vol. 8, No. 11, Nov, 2018, E-ISSN: 2222-6990 @ 2018 HRMARS

within the EMU. Applied Economics Letters, 10(12), 799-804. http://doi.org/10.1080/1350485032000126758

Arku, G. (2006). The housing and economic development debate revisited: economic significance of housing in developing countries. Journal of Housing and the Built Environment, 21(4), 377-395. http://doi.org/10.1007/s10901-006-9056-3

Atalay, K., Barrett, G., and Edwards, R. (2015). House prices, mortgage debt and labour supply: evidence from Australian households. AHURI Positioning Paper No.167, Melbourne: Australian Housing and Urban Research Institute Limited, 2-59. http://doi.org/10.18408/ahuri-7304101

Bank Negara Malaysia (2015). Annual Report 2015 - Economic developments in 2015. Retrieved March 10, 2017 from http://www.bnm.gov.my/index.php?ch=en_publication\&pg=en_ ar\&ac=22\&en

Bank Negara Malaysia. (2017). Risk developments and assessment of financial stability in 2017. Retrieved May 10, 2018 from http://www.bnm.gov.my/index.php?ch=en_publication\& pg=en_fspr\&ac $=23 \&$ en

Bollano, E., and Ziu, G. (2009). Developments in the residential housing market: house prices, credit and consumption interrelation empirical evidence, the Albanian case. In International Conference on Applied Economics - ICOAE 2009 (pp. 79-88).

Brooks, C. (2008). Introductory Econometrics for Finance (Second Edition). Cambridge University Press.

Brown, M., Haas, R. De, and Grosjean, P. (2012). Household debt and economic vulnerability during the Great Recession. European Bank for Reconstruction and Development.

Chawla, R. K. (2011). The distribution of mortgage debt in Canada. Statistics Canada, pp. 1-7. Retrieved April 5, 2017 from http://www.statcan.gc.ca/pub/75?001?x/2011002 /article/11429?eng.htm

Citibank (2018). Property Insights: Quarter 1, 2018. Retrieved September 5, 2017 from https://www.citibank.com.my/english/docs/pdf/market-trends/CB_MY_Q1_2018.pdf

Consumer Financial Protection Bureau (CFPB) (2014). Manufactured-housing consumer finance in the United States. Retrieved April 5, 2017 from https://www.consumerfinance.gov/dataresearch/research-reports/manufactured-housing-consumer-finance-in-the-u-s/

Crawford, A., and Faruqui, U. (2012). What Explains Trends in Household Debt in Canada? Bank of Canada Review. Retrieved April 5, 2017 from https://www.baedmundcinkofcanada.ca/wpcontent/uploads/2012/02/boc-review-winter11-12-crawford.pdf

Department of Statistics Malaysia Official Portal (2015). Prices. Retrieved March 1, 2017 from https://www.dosm.gov.my/v1/index.php?r=column/cone\&menu_id=WXgySGFleW9XOWh5eG FzNWtHK1NtZz09

Dickey, D. A., and Fuller, W. A. (1981). Likelihood ratio statistics for autoregressive time series with a unit root. Econometrica, 49(4), 1057-1072. http://doi.org/10.2307/1912517

Dynan, K. E., and Kohn, D. L. (2007). The rise in U.S. household indebtedness: causes and consequences. FEDS Working Paper No. 2007-37.

Eccleston, R., Churchill, B., and Smith, H. (2014). Cost of living pressures on Tasmanian households: causes and options for reform. University of Tasmania.

Ehrmann, M., and Ziegelmeyer, M. (2017). Mortgage choice in the Euro area: macroeconomic 
determinants and the effect of monetary policy on debt burdens. Journal of Money, Credit and Banking, 49(2-3 (March-April 2017)), 469-494. http://doi.org/10.1111/jmcb.12386

Foote, C. L., Loewenstein, L., and Willen, P. S. (2016). Cross-sectional patterns of mortgage debt during the housing boom: evidence and implications. National Bureau of Economic Research Working Paper Series (Vol. No. 22985).

Fortin, M. (2014). Why has the mortgage debt increased by so much in Canada? GREDI Working Paper 15-03, 1-42.

Geiger, F., Muellbauer, J., and Rupprecht, M. (2016). The housing market, household portfolios and the German consumer. European Central Bank (ECB) Working Paper Series.

Gerlach, S., and Peng, W. (2005). Bank lending and property prices in Hong Kong. Journal of Banking \& Finance, 29(2), 461-481. http://doi.org/10.1016/J.JBANKFIN.2004.05.015

Goh, J. (2017, July 18). Interest seen returning to mortgage market. The Edge Malaysia Weekly, Retrieved June 1, 2017 from http://www.theedgemarkets.com/article/interest-seen-returningmortgage-market.

ih, N., and Meng, S. (2015). The rising Australian household debt: results from a Bayesian VAR analysis. Unpublished Paper, 1-30.

Igan, D., Kabundi, A., Nadal De Simone, F., Pinheiro, M., and Tamirisa, N. (2011). Housing, credit, and real activity cycles: characteristics and co-movement. Journal of Housing Economics, 20, 210231. http://doi.org/10.1016/j.jhe.2011.07.002

International Monetary Fund (2017). Global Financial Stability Report 2017 - Chapter Two: Household debt and financial stability. Retrieved from https://www.imf.org/en/Publications/GFSR/Issues/2017/09/27/global-financial-stability-re port-october-2017

Jacobsen, D. H., and Naug, B. E. (2004). What influences the growth of household debt? Norges Bank Economic Bulletin, 75(3), 103-111.

Jasthi, S. (2015). Cost of living and debt, state by state. Nerdwallet. Retrieved April 5, 2017 from https://www.nerdwallet.com/blog/credit-cards/cost-of-living-debt-metros-states/

Kok, C. (2016). Many Malaysian households at risk of shocks. The Star Online. Retrieved April 5, 2017 from https://www.thestar.com.my/business/business-news/2016/09/03/many-malaysianhouseholds-at-risk-of-shocks/

Leece, D. (2006). Testing a basic theoretical model of mortgage demand on United Kingdom Data. Applied Economics, 38(17), 2037-2051. http://doi.org/http://dx.doi.org/10.1080 /00036840500426959

Ma'in, M., Ismarau Tajuddin, N. A., and Saiful Nathan, S. B. (2016). Household debt and macroeconomic variables in Malaysia. In BE-ci 2016: 3rd International Conference on Business and Economics, $21 \quad-23$ September, $2016 \quad$ (pp. 121-130). http://doi.org/10.15405/epsbs.2016.11.02.12

Marsden, J. (2015). House prices in London - an economic analysis of London's housing market. Greater London Authority Economics, 72(November), 1-62.

Martins, N., and Villanueva, E. (2004). The impact of interest-rate subsidies on long-term household debt: evidence from a large program. DNB Working Paper, (No. 026/2004), 1-34.

Martins, N., and Villanueva, E. (2009). Does high cost of mortgage debt explain why young adults live 
INTERNATIONAL JOURNAL OF ACADEMIC RESEARCH IN BUSINESS AND SOCIAL SCIENCES

Vol. 8, No. 11, Nov, 2018, E-ISSN: 2222-6990 @ 2018 HRMARS

with their parents? Journal of the European Economic Association, 7(5), 974-1010. http://doi.org/https://doi.org/10.1162/JEEA.2009.7.5.974

Mian, A., and Sufi, A. (2009). The consequences of mortgage credit expansion: evidence from the U.S. mortgage default crisis. The Quarterly Journal of Economics, 124(4), 1449-1496. https://doi.org/10.1162/qjec.2009.124.4.1449

Nizar, N. (2016). Determinants of Malaysia household debt: macroeconomic perspective. Journal of Business and Economics, 7(8), 1234-1245. http://doi.org/10.15341/jbe(21557950)/08.07.2016/005

Panagiotidis, T., and Printzis, P. (2015). On the macroeconomic determinants of the housing market in Greece: a VECM approach. GreeSE Paper No.88 Hellenic Observatory Papers on Greece and Southeast Europe, 1-40. http://doi.org/10.1007/s10368-016-0345-3

Pettinger, T. (2017). Factors that affect the housing market. Economics Help. Retrieved May 3, 2017 from https://www.economicshelp.org/blog/377/housing/factors-that-affect-the-housingmarket/

Saeed, M. J. (2011). Issues and potential of Islamic home finance in Pakistan. Business Recorder. Retrieved May 3, 2017 from http://www.sbp.org.pk/departments/ihfd/Nov-12/house/ Issues and potential of Islamic home finance in Pakistan.pdf

Schelkle, T. (2018). Mortgage default during the U.S. mortgage crisis. Journal of Money, Credit and Banking, 50(6), 1101-1137. http://doi.org/10.1111/jmcb.12546

Stockhammer, E., and Wildauer, R. (2017). Expenditure cascades, low interest rates or property booms? Determinants of household debt in OECD Countries. Post Keynesian Economics Study Group. Retrieved October 1, 2018 from http://www.nowpublishers.com/article/Details/RBE0083

Tong, A. (2018). Restructuring our household debt. The Star Online. Retrieved October 2, 2018, from https://www.thestar.com.my/business/business-news/2018/02/10/restructuring-our household-debt/

Valverde, S. C., and Fernández, F. R. (2010). The relationship between mortgage markets and house prices: does financial instability make the difference? Federal Reserve Bank of Atlanta Centre for Financial Innovation and Stability (CenFIS) Working Paper, 10(02), 1-23. http://doi.org/https://dx.doi.org/10.2139/ssrn.1547247

Zabai, A. (2017). Household debt: recent developments and challenges. BIS Quarterly Review, (December), 39-54.

Zivot, E., and Wang, J. (2006). Unit Root Tests. In Modelling Financial Time Series with S-PLUS (pp. 111-139). Springer-Verlag New York. http://doi.org/10.1007/978-0-387-32348-0 